Article

\title{
Can Leaders' Humility Enhance Project Management Effectiveness? Interactive Effect of Top Management Support
}

\author{
Mudassar Ali ${ }^{1, *(\mathbb{D}, \text { Li Zhang }}{ }^{1}$, Zhenduo Zhang ${ }^{2}$, Muhammad Zada ${ }^{3} \mathbb{C}$, Abida Begum ${ }^{4}$, Heesup Han ${ }^{5, * \mathbb{C}}$, \\ Antonio Ariza-Montes ${ }^{6}\left(\mathbb{D}\right.$ and Alejandro Vega-Muñoz ${ }^{7}$ (i)
}

1 School of Management, Harbin Institute of Technology, Harbin 150001, China; zhanglihit@hit.edu.cn

2 School of Economics and Management, Dalian University of Technology, Dalian 116000, China; zhangzhenduo12@mails.ucas.ac.cn

3 College of Business, Henan University, Kaifeng 475004, China; m.zada1@hotmail.com

4 Ideological and Political Education Department, School of Marxism, Northeast Forestry University, Harbin 150040, China; abidakhg@gmail.com

5 College of Hospitality and Tourism Management, Sejong University, 98 Gunja-Dong, Gwanjin-Gu, Seoul 143-747, Korea

6 Social Matters Research Group, Universidad Loyola Andalucía, C/ Escritor Castilla Aguayo No. 4, 14004 Cordoba, Spain; ariza@uloyola.es

7 Public Policy Observatory, Universidad Autonoma de Chile, Santiago 7500912, Chile; alejandro.vega@uautonoma.cl

* Correspondence: mudassarsalamat@gmail.com (M.A.); heesup.han@gmail.com (H.H.)

Citation: Ali, M.; Zhang, L.; Zhang, Z.; Zada, M.; Begum, A.; Han, H.; Ariza-Montes, A.; Vega-Muñoz, A. Can Leaders' Humility Enhance Project Management Effectiveness? Interactive Effect of Top Management Support. Sustainability 2021, 13, 9526. https://doi.org/10.3390/su13179526

Academic Editor: Seung-Wan Kang

Received: 16 July 2021

Accepted: 19 August 2021

Published: 24 August 2021

Publisher's Note: MDPI stays neutral with regard to jurisdictional claims in published maps and institutional affiliations.

Copyright: () 2021 by the authors. Licensee MDPI, Basel, Switzerland. This article is an open access article distributed under the terms and conditions of the Creative Commons Attribution (CC BY) license (https:// creativecommons.org/licenses/by/ $4.0 /)$.

\begin{abstract}
This paper aims to explore the effect of humble leadership on project management effectiveness by integrating the mediating role of employee creativity. Top management support moderates the direct (humble leadership and project management effectiveness) and indirect relationships through employee creativity. Time-lagged data were obtained from 332 persons working in a matrix organization on sustainable information technology projects. The results show that humble leadership enhances project management effectiveness by mediating and moderating processes. This study provides a solution to an underlying research question that has gone unanswered in prior studies. What are the strategies proposed for humble leadership in fostering the effectiveness of project management?
\end{abstract}

Keywords: humble leadership; employee creativity; top management support; project management effectiveness

\section{Introduction}

Researchers and practitioners have recognized the vital eminence indicators that condition projects [1]. Based on numerous features that affect project management effectiveness, the position of the project manager is crucially essential [2]. Some scholars agree that the leadership position of manager is critical for the effectiveness of a project [3]. The project manager discusses, guides and encourages followers to accomplish their goals [4]. Recently, scholars have started to study growing aspects of leadership to contribute to the progress of projects [5]. Among all the traits of leaders, humility can be an important antecedent of project management effectiveness. Ali et al., [6] defined humble project managers as practicing a pure form of relational leadership with an appreciation for the contributions of followers. Consequently, the above research indicates that the link between humble leadership and project management effectiveness should be investigated.

This research aims to understand other processes through which project managers mark project management effectiveness with their humble leadership behavior. Ali et al., [7] call for additional research to explain the connection between humble project managers and their project's effectiveness through mediators that signify creativity. Employee creativity raises valuable ideas from individuals or working groups [8]. Humble leadership is 
embodied in the recognition of a subordinate's skills, which builds self-confidence in the innovative thinking they can offer in their area of expertise [9]. Zheng et al., [10] emphasize the need for empirical work on the essential nature of creativity in the context of project management. Given this gap, the current research investigates the critical approach of employee creativity as a mediator between humble leadership and project management effectiveness.

Furthermore, this study investigates top management support as the confining form for humble leadership to influence project management effectiveness. Standing concepts and studies directly state that project managers and senior management assistance are simultaneously significant in project management effectiveness [11]. Previous research has emphasized that superior management support is critical at various project stages [12]. However, few studies have examined the effects of interactive leadership and superior management backing on project effectiveness [13]. This literature gap is significant because the excellent leadership skills of project managers cannot be effective for projects until top management supports them. Earlier studies suggest that leaders' humility emphasizes different facets of the innovation cycle, accommodating an overall nurturing atmosphere to support his/her influences [14]. This support considers top managements' contribution to increasing project management effectiveness. This research introduces top management support of creativity that can interlink with humble leadership and project management effectiveness. Previous literature has shown that top management support is essential between leadership and creativity, earning scant attention as a moderator [15]. Much research has called for a need to investigate the boundary conditions for the use of humble leadership behaviour [16]; subsequently, the current study examines how top management assistance may act as a boundary basis for the motivational impact on humble leader behaviour.

Based on the preceding discussion, the current study proposes a theoretical model in which a humble leader is linked, both directly and indirectly, to robust project management effectiveness (via innovative work behaviour). The goal of this research is to accord significantly to the existing literature by developing the structure. This research will extend our view of the leadership dimension by expanding the previous findings on a leadership position in project performance with followers' psychological factors [17]. The study further strengthens the current knowledge of resource theory. Hobfoll [18] added the principle premises to the theory's assumptions to the model of this study. Hobfoll [18] described a leader as a resource that aids workers to cope with their resources. The resource paradigm conservation should provide insight into how humble leadership relates to resource regulations methods that improve project management effectiveness, drawing further on the assumptions of "caravans passageways" in resource theory [19]. Top management support functions, such as a resource caravan passageway (i.e., a procedure that supports, regulates, routes and provide resources), providing a desirable supportive atmosphere that enables humble leaders to activate employees' creativity, hence improving project management effectiveness.

Finally, this research examines the link between humble leadership and project management effectiveness. This may help to better understand the relationship between bottom-up leadership practices in project management. Second, employee creativity is critical in mediating the connection between humble leadership and project management effectiveness. Third, we examine top management support as the moderator that creates favourable support that enables a humble leader to achieve robust employee creativity and project management effectiveness.

\section{Humble Leadership}

Humble leadership is characterized by three attributes: readiness to look closely and to appreciate the qualities of others and receptiveness to fresh ideas and criticism [20]. As an interactive attribute, a leader that practices humble leadership is one who identifies followers in social connections. Prior literature has recognized several humble leader 
conduct peculiarities [21]. In particular, a leader's humility means they are eager to evaluate themselves without negative or positive overstatement, signifying that the leader has a correct, impartial and sensible view [22]. Humble leaders recognize the worth and talents of adherents and open-heartedly provide strength to others [14]. Humble leaders are proactive to original perspectives, suggestions and knowledge from their subordinates, fostering a culture of collaboration, faith, inventiveness and competence [23]. Humble leaders treat their subordinates with compassion by being polite, seeking advice and urging staff to eliminate power hierarchies [24]. Humble leaders provide a safe space for workers to express their problems openly [25].

\section{Top Management Support}

The concept of top management is a fascinating phenomenon [26]. Top management is a group of senior policymakers comprising the chief executive officer, chief operating officer, chief financial officer, leaders of business segments and vice president [13]. Along with its involvement in planning the project and assisting the project manager in guaranteeing its effective execution, top management is a crucial project stakeholder [27]. According to Boonstra [28], top management formulates a series of collaborative core values in resolving overall environmental impacts and organisational design challenges that have typically been conducted successfully and are thus deemed valid within the setting of a particular organisation. Maqbool and Sudong [29] claimed that top management support is critical to the effectiveness of projects management.

\section{Employee Creativity}

Employee creativity is a collection of behavioural activities representing an employee attitude toward their work role, such as idea creation, advancement and recognition [30]. Idea creation includes innovative goods, services, or procedures, entrance into new markets, changes in existing work procedures, or, generally speaking, solutions to current problems [31]. Idea advancement refers to one worker who develops an idea that he/she wants to participate in social activity to find mates, supporters and sponsors behind an idea or build a network of supporters with the necessary power behind it [32]. Idea recognition is a process of creating typical creativity that can be experienced and ultimately applied to an individual, a group, or overall organisation [33].

\section{Project Management Effectiveness}

Project management effectiveness may be defined in several ways [34]. The UK Association of Project Management defines effectiveness differently. It describes project management as a process of planning, controlling, evaluating, analysing and regulating every aspect of a project to meet objectives precisely and within the timeline, budget and overall quality constraints [11]. Ultimately, effectiveness is not the extent of how successfully a company and its workers accomplish valuation operations, but rather how equally distinct roles collaborate and are synchronized [35]. A firm cannot function adequately from a managerial standpoint unless the employees successfully do the essential jobs [36]. The effectiveness of projects is assessed with how effectively they support the fulfilment of the organisational missions, although the project productivity is gauged through how it is being carried out. The present research illustrates that project management effectiveness is the amount wherein the project meets its objectives through proper planning, offers business and advantages to stakeholders and concludes within the timeline, intended cost and quality [35].

\section{Humble Leadership and Project Management Effectiveness}

Prior literature suggests that humble leadership is vital for workplace outcomes, such as team effectiveness and project outcomes [37,38]. Still, project leadership work remains relatively scarce $[5,39]$ and humble project managers in a project context may vary substantially, compared to permanent organisations [40]. Leaders' humility promotes 
team unity and collective conception and encourages sharing and logical interpretation among followers [41]. Cohesion, coordination and solidity at a reasonable level create an environment in which followers continue their efforts to raise project effectiveness [42]. Humble leadership empowers team members and gives importance to their ideas through the delegation of power [43]. Devolution of authority and involvement in target setting improve followers efficiency, which is a necessary condition for conflict management, problem-solving techniques and goal-oriented decision-making to affect projects [44]. Such humble leadership behaviour improves the followers' morale and enhances the open sharing of ideas through feedback [45]. It creates an environment where followers focus on addressing their deficiencies to meet performance requirements, allowing them to work effectively and run the project management effectively [11].

Byrne, Dionisi [46] revealed that the leader might be described as a source that generates insight into the organisation by positively developing the followers or conserving resources. Furthermore, leaders' humility is a significant personal resource that enhances subordinates' trust to build an atmosphere of collaboration and teamwork, leading to project management effectiveness. Therefore, it is suggested that

Hypothesis 1 (H1). Humble leadership is positively related to project management effectiveness.

\section{The Mediating Role of Employee Creativity}

Past studies explained that humble leadership is strongly associated with creative conduct [14]. A humble project manager values the commitment of subordinates, treats followers with kindness, appreciation and reverence, resulting in the assistants developing helpful ideas [47]. Humble leaders also respect the feedback of followers and recommendations that facilitate the subordinates to promote the ideas and strengthen their expertise level [14,48]. A humble leader accepts the errors and shortcomings of followers as a medium for growth and progress. Consequently, subordinates are more likely to exhibit more meaningful risk-taking conduct [49]. They find their immediate boss to encourage this conduct by either providing sufficient incentives or refusing discipline in the event of failure to produce desirable results [50]. As a result, employees are secure enough to openly present suggestions to leaders and trust them to notice and act coherently [32]. Humble leadership encourages followers to produce fresh ideas and generates an environment where innovative approaches are encouraged to inspire workers to establish inventive solutions before a suitable method is selected [6]. Furthermore, the humble leader makes their subordinates resilient toward precariousness by teachability and responsiveness to criticism and encourages their team members to attempt new things based on trial and error (Mallén et al., 2019) that stimulates creativity among them the followers [51].

Earlier studies showed that creativity meets organisational objectives [52,53]. Project team members able to produce fast solutions can address organisational and technological challenges in time and improve projects [54,55]. Creative work frequently relies on increasing the productivity of the workplace as creative. Team members predict and recognise visions for growth and craft new solutions in their workplaces [56], thereby allowing them to succeed in a competitive atmosphere [57]. Duan, Cao [58] submitted that employees' creativity is promoted because it is a powerful method for overcoming problems in a dynamic atmosphere. A sufficient amount of employees' inventiveness can follow in increasingly creative procedures and ambitious skills to transform these advantages into project management effectiveness [34]. Creativity aims to increase the importance of projects and improve the perception that such behaviour positively influences their effectiveness and achieves objectives $[59,60]$.

This implies that a humble leader stimulates creativity in order to complete project management effectively. Therefore, creativity serves as a fundamental structure that allows humble leadership to impact project management effectiveness. Founded on conservation of resource theory 18, taking humble leadership as a constructive resource through their behaviours enables subordinates to spend their resources on flexible behaviours (i.e., 
employee creativity). In addition, as a corollary, they are motivated to develop more resources, bringing effective project management. Based on the above discussion, the following hypotheses are proposed:

Hypothesis 2 (H2a). Humble leadership is positively related to employee creativity.

Hypothesis $\mathbf{2} \mathbf{( H 2 b ) . ~ E m p l o y e e ~ c r e a t i v i t y ~ i s ~ p o s i t i v e l y ~ a s s o c i a t e d ~ t o ~ p r o j e c t ~ m a n a g e m e n t ~ e f f e c t i v e n e s s . ~}$

Hypothesis 2 (H2c). Employee creativity favourably mediates the relationship between humble leadership and project management effectiveness.

\section{The Moderating Role of Top Management Support}

The most crucial factor is top management support, which can moderate humble leadership and project outcomes. Superior management refers to the elite decision-makers of an organisation, such as managing director, chief executive officer, executive chairman, chief financial officer, president and vice president [61]. Superior management has a critical role in planning and supporting a project manager to ensure that the project is executed effectively [62,63]. Schultz, Graw [64] revealed that top management assistance is the triumph aspect for ventures and reinforces the connection between leadership and employee innovation and project management effectiveness.

Using the concepts of the resource conservation theory [65], top management support can be characterised, in the work environment of the project managers, as resource caravan passageways that can help them acquire and build additional resources, such as engaging in humble leadership behaviour. Top management support is motivated to accomplish its goals by accordance with acknowledgement standards, strategies, budgeting, providing human, material and technical resources [12] and through fulfilling all capacity parameters by improving the project managers' confidence within the organisation [66]. Top management support can impact project progress through its processes, such as appointing project managers, establishing an internal project supportive system, providing project resources and project methods [67]. Project-based organisations experience difficulties and workers in such organisations encounter workplace challenges and day-to-day stress [26]. Under these conditions, in association with superior managerial support, the humble leader may significantly influence project management effectiveness.

It has to be acknowledged that humble leadership behaviours exist in the framework of the organisation and evaluating a bivariate connection is insufficient, unless the top management support system in which creativity is conducted is recognised [68]. Therefore, it is obligatory to classify and analyse the top management's support qualities that may interrelate with humble leadership behaviours affecting creativity. Creative behaviours are an essential motivation source and have been a topic in leadership and invention research [69]. The motivation for creative conduct is mainly dependent on top management support that fuels innovation [66]. Strengthening and encouraging creative activities should provide a perspective of the process, methods, strategies, etc. of an organisation. Accordingly, the organisation would be viewed based on specific communicative patterns, attitudes and emotions [70], promoting creativity. Innovative behaviours are strongly related to top management support because the executives are the ones who set organisational targets, make decisions on bringing and implementing innovative forms of doing jobs and inspiring employees [71]. The encouragement of creative behaviours in the organisation gives workers and leaders an energetic working atmosphere, leading to creativity. Workers can speak out as they observe they are motivated by humble leadership through top management support. Under these conditions, employees are likely to transmute ideas into innovative outcomes because a stable climate for innovation stimulates them. Besides, when employees notice humble leadership, they imitate their leaders to share views and ideas; transforming these ideas into innovative results requires an innovative environment [47].

According to the concept of resource caravan passageways, the capability of individuals to design and retain their stream of resources relies mainly on circumstances outside 
their influence [72]. Ali, Li [7] revealed that top management support is an environmental variable that can help, encourage, augment and preserve the possessions of persons, groups, or sections of workers. Humble leadership and followers believe that senior management is concerned about resources and perceive to have sufficient resources at work. Hence, we suggest that top management interacts with humble leadership and creativity and acts as moderator in direct and indirect linkages between humble leadership and project management effectiveness.

Hypothesis 3 (H3a). Top management support moderates the relationship between humble leadership and project management effectiveness, such that senior management support strengthens the relationship.

Hypothesis $3 \mathbf{~} \mathbf{H} \mathbf{3 b})$. Top management support moderates the relationship between humble leadership and creativity, such that higher management support strengthens the relationship.

Hypothesis 3 (H3c): The indirect effect of humble leadership through creativity on project management effectiveness is likely significant for high top management support and nonsignificant for those with low top management support.

\section{Methodology}

Sampling and Research Tool

Data were obtained from four major information technology companies operating in Pakistan, engaging in natural sustainable resource production and healthcare. These industries aid in developing and strengthening sustainable resources, sustainable software design, network structure, sustainable and renewable building landscape architecture and assistance with e-commerce and worker coaching to comprehend updated software tools and techniques. The survey was conducted in English, which is part of education in most educational institutions in Pakistan. We approached the directors of work units and requested approval to gather data from the employees working within their jurisdiction. After obtaining their authorization, employees were conversant of the study aim and guaranteed that personal data would be kept secret and utilized solely for research purposes. After demonstrating their concurrence, they were handed surveys, which they were requested to hand back in a sealed envelope. While answering the questionnaires, respondents were requested to assess their overall opinion on previous project deliverables. Moreover, data were collected from project leaders, team leaders and project team members. We followed this procedure as previously suggested and accomplished [17,73-76]. We performed data analysis through confirmatory factor analysis, structural equation modelling and process methods as previous studies suggested and accomplished [77,78]. The time-lagged data collection technique was used at two time intervals with a time lag of three months to reduce the common method bias. At the first time (T1) interval, demographics, humble leadership and top management support data were collected. At the second time (T2) interval, we collected data on employee creativity and project management effectiveness from the same respondents targeted in the first survey. Out of 550 circulated questionnaires, 511 questionnaires were returned. The number of responses was pretty positive in the follow-up survey and, out of the 511 questionnaires that were returned, 179 were dropped because of careless responses. Three hundred thirty-two questionnaires were used for analysis, with a 60.36 percentage. The demographics of the study respondents are presented in Table 1. 
Table 1. Demographic profile of respondents.

\begin{tabular}{cccc}
\hline Measures & Item & Frequency & Percentage \\
\hline Gender & Male & 210 & 63.2 \\
& Female & 122 & 36.8 \\
Age (years) & $20-30$ & 81 & 24.9 \\
& $31-40$ & 92 & 27.6 \\
& $41-50$ & 86 & 25.5 \\
Education & Above 51 & 73 & 22.0 \\
& Bachelors & 237 & 71.5 \\
Work Experience & Master & 65 & 19.0 \\
& Diploma & 30 & 9.5 \\
& Less than 5year & 25 & 7.4 \\
& 5-10 years & 100 & 30.6 \\
& 11-15 years & 131 & 39.5 \\
& 16 years and above & 76 & 22.6 \\
\hline
\end{tabular}

\section{Measures}

From past literature, the focal construct methods were implemented. All measures were anchored on a 5-point rating scale from strongly disagree (1) to strongly agree (5). Humble leadership was measured with the 9-items scale developed by Owens, Johnson [79], with an alpha reliability of 0.93 . Project management effectiveness was measured with the 10-item scale developed by Ong and Bahar [11], with 0.94 alpha reliability. The 6-item scale of top management support was developed by Islam, Doshi [80], with 0.89 alpha reliability. Employee creativity was measured with 13 items developed by George and Zhou [8], with 0.91 alpha reliability. Employee creativity items gauged from not all characteristic (1) to very characteristic (5). Work experience, gender, age and education level are included as control variables.

\section{Data Analysis}

Data analysis was performed using SPSS 23 and AMOS 23. The analysis was performed in two steps, confirmatory factor analysis (CFA) and structural model testing. CFA is a preliminary step in the data analysis process to confirm whether the measured items underlie the hypothesised latent variables [81]. Then, relationships among the hypotheses are tested using a structural equation model (SEM) [82].

\section{Composite Reliability (CR) and Average Variance Extracted (AVE)}

Composite reliability (CR) and average variance extracted (AVE) can be used to confirm convergent and discriminatory validity [83]. The $C R$ values were higher than 0.90 , with solid consistency in all constructs $[84,85]$. By utilising the average variance retrieved, convergent validity was confirmed. To establish convergent validity amongst the study structures, AVE values should be larger than 0.5 [86]. All constructs had an AVE value higher than 0.5 , indicating no difficulty with convergent validity. Discriminant validity was tested following the Fornell-Larcker approach [84]. The criterion was fulfilled, since the square root of the AVE value of all the constructs was greater than the correlation among all the constructs, as given in Table 2 (the square root of AVE is given in diagonal with bold letters). 
Table 2. Mean, standard deviation, validity and correlation.

\begin{tabular}{ccccccccc}
\hline & CR & Mean & SD & AVE & EC & PME & HL & TMS \\
\hline EC & 0.91 & 3.5 & 0.85 & 0.55 & 0.74 & & & \\
\hline PME & 0.94 & 3.8 & 0.83 & 0.61 & $0.27^{* *}$ & 0.78 & & \\
\hline HL & 0.93 & 3.6 & 0.79 & 0.58 & $0.19^{* *}$ & $0.18^{* *}$ & 0.761 & \\
\hline TMS & 0.89 & 3.5 & 0.77 & 0.58 & $0.17^{* *}$ & $0.19^{* *}$ & -0.063 & 0.764 \\
\hline
\end{tabular}

Notes: variances extracted are on the diagonal, correlations are off diagonal. ${ }^{* *} p<0.01$ (two tailed). Note: variances extracted are on the diagonal; correlations are off diagonal. AVE $=$ average variance extracted; $\mathrm{CR}=\mathrm{com}$ posite reliability; $\mathrm{HL}$ = humble leadership; $\mathrm{EC}=$ employee creativity; $\mathrm{PME}=$ project management effectiveness; TMS $=$ top management support

\section{Measurement Model}

Confirmatory factor analysis (CFA) confirmed the model fit before the hypothesis was tested [87]. To study the possibility of the best fit model, conventional models fit statistics, including $\chi^{2}$, the root mean square error of approximation (RMSEA), the Tucker-Lewis index (TLI) and the comparative fit index (CFI), were cast-off as a model fit gauge [81]. When $\chi^{2}$ is substantial, the CFI and TLI are larger than 0.9 and the RMSEA is less than or equal to 0.08 , the model is measured to have adequate appropriateness [22]. Founded on these approaches as suggested by past studies [88,89], we performed a sequence of model comparison assessments to confirm the model. The hypothesized model (M0) provided a good fit $\left(\chi^{2}=779.7, \chi^{2} / \mathrm{df}=1.49, \mathrm{RMSEA}=0.038, \mathrm{CFI}=0.96, \mathrm{NFI}=0.896\right.$ and TLI $\left.=0.96\right)$. In the first alternative two-factor model (M1) $(\mathrm{F} 1=\mathrm{HL}+\mathrm{PME}, \mathrm{F} 2=\mathrm{EC}+\mathrm{TMS}),\left(\chi^{2}=3475.2\right.$, $\chi^{2} / \mathrm{df}=6.6, \mathrm{RMSEA}=0.129, \mathrm{CFI}=0.576, \mathrm{NFI}=0.537$ and TLI $\left.=0.547\right)$, compared to the hypothesized model, $\chi^{2}$ increased by $2695.5, \chi^{2} / \mathrm{df}$ increased by 6.6, NFI, TLI and CFI decreased by $0.359,0.413$ and 0.384 , respectively, whereas the RMSEA increased by 0.091 . In the second alternative two-factor model (M2) $(\mathrm{F} 1=\mathrm{HL}+\mathrm{EC}, \mathrm{F} 2=\mathrm{TMS}+\mathrm{PME}),\left(\chi^{2}=3299.4\right.$, $\chi^{2} / \mathrm{df}=6.27, \mathrm{NFI}=0.561, \mathrm{CFI}=0.601, \mathrm{TLI}=0.956$ and RMSEA $\left.=0.125\right)$, however, compared to the hypothesized four-factor model, $\chi^{2}$ increased by $2519.7, \chi^{2} / \mathrm{df}$ increased by 4.78 , NFI, TLI and CFI decreased by $0.335,0.386$ and 0.359 , respectively, whereas the RMSEA slightly raised by 0.087 . In the third alternative, the three-factor model (M3) (F1 = HL + EC, $\mathrm{F} 2=\mathrm{TMS}, \mathrm{F} 3=\mathrm{PME}),\left(\chi^{2}=2311.8, \chi^{2} / \mathrm{df}=4.412, \mathrm{NFI}=0.69, \mathrm{CFI}=0.74, \mathrm{TLI}=0.72\right.$ and RMSEA $=0.101$ ) did not offer better fit than the hypothesized four-factor model either, as $\chi^{2}$ increased by $1703.3, \chi^{2} / \mathrm{df}$ raised by $3.24, \mathrm{NFI}$, TLI and CFI decreased by $0.236,0.27$ and 0.25 , respectively, whereas RMSEA slightly increased by 0.067 . In the third alternative, the three-factor model (M4) (F1 = HL + EC, F2 = TMS, F3 = PME), $\left(\chi^{2}=2311.8, \chi^{2} / \mathrm{df}=4.412\right.$, $\mathrm{NFI}=0.69, \mathrm{CFI}=0.74, \mathrm{TLI}=0.72$ and $\mathrm{RMSEA}=0.101)$ did not offer better fit than the hypothesized four factor model either, as $\chi^{2}$ increased by $1703.3, \chi^{2} / \mathrm{df}$ raised by 3.24 , NFI, TLI and CFI decreased by $0.236,0.27$ and 0.25 , respectively, whereas RMSEA slightly increased by 0.067 . The last single-factor model (M5) $\left(\chi^{2}=4904.9, \chi^{2} / \mathrm{df}=9.3, \mathrm{NFI}=0.34\right.$, $\mathrm{CFI}=0.37$, TLI $=0.33$ and $\mathrm{RMSEA}=0.157$ ) did not offer a better fit than the hypothesized four-factor model either, as $\chi^{2}$ increased by $4125.2, \chi^{2} / \mathrm{df}$ raised by $7.81, \mathrm{NFI}, \mathrm{TLI}$ and CFI decreased by $0.556,0.63$ and 0.59 , respectively, whereas RMSEA increased by 0.119 . Thus, the hypothesized four-factor model was better than all alternative models (see Table 3).

Table 3. Confirmatory factor analysis of the measures.

\begin{tabular}{|c|c|c|c|c|c|c|}
\hline Models & $x^{2}$ & $\chi^{2} / d f$ & NFI & TLI & CFI & RMSEA \\
\hline Hypothesized 4 factor Model (M0) & 779.7 & 1.49 & 0.896 & 0.96 & 0.96 & 0.038 \\
\hline Two Factors Model (F1 = HL + PME, F2 = EC + TMS) (M1) & 3475.2 & 6.6 & 0.537 & 0.547 & 0.576 & 0.129 \\
\hline Two Factors Model (F1 = HL + EC, F2 = TMS + PME) (M2) & 3299.4 & 6.27 & 0.561 & 0.574 & 0.601 & 0.125 \\
\hline Three Factors Model (F1 = HL + EC, F2 = TMS, F3 = PME) (M3) & 2311.8 & 4.412 & 0.69 & 0.72 & 0.74 & 0.101 \\
\hline Three Factors Model (F1 = HL + PME, F2 = EC, F3 = TMS) (M4) & 2483 & 4.73 & 0.66 & 0.69 & 0.71 & 0.105 \\
\hline Single Factor Model (M5) & 4904.9 & 9.30 & 0.34 & 0.33 & 0.37 & 0.157 \\
\hline
\end{tabular}

$\mathrm{HL}$ = humble leadership; EC = employee creativity; PME = project management effectiveness; TMS = top management support. 


\section{Structural Model Testing}

The SEM findings of direct links for the proposed model are represented in Table 4. Regarding the significant effect, the investigation revealed a significant positive connotation between humble leadership and project management effectiveness $(\beta=0.15, p<0.001)$, aiding $\mathrm{H} 1$. H2a also aided the notion of humble leadership as an essential predictor of employee creativity $(\beta=0.18, p<0.001)$. Similarly, in the case of $\mathrm{H} 2 \mathrm{~b}$, the findings report a strong relationship of employee creativity $(\beta=0.21, p<0.001)$ with project management effectiveness; thus, it was approved. It is essential to highlight that the controls were insignificantly related to project management effectiveness except for gender. These results did not influence the relationships among the study variables.

Table 4. Structural equation model path analysis results.

\begin{tabular}{|c|c|c|c|c|c|}
\hline & Path & & Coefficient & SE & $t$-Value \\
\hline \multicolumn{6}{|c|}{ Controls } \\
\hline Age & $\rightarrow$ & $\begin{array}{l}\text { Project } \\
\text { Management } \\
\text { Effectiveness }\end{array}$ & 0.018 & 0.04 & 0.32 \\
\hline Education & $\rightarrow$ & $\begin{array}{l}\text { Project } \\
\text { Management } \\
\text { Effectiveness }\end{array}$ & -0.10 & 0.06 & -0.16 \\
\hline $\begin{array}{l}\text { Work } \\
\text { Experience }\end{array}$ & $\rightarrow$ & $\begin{array}{l}\text { Project } \\
\text { Management } \\
\text { Effectiveness }\end{array}$ & -0.12 & 0.05 & -2.50 \\
\hline Gender & $\rightarrow$ & $\begin{array}{l}\text { Project } \\
\text { Management } \\
\text { Effectiveness }\end{array}$ & 0.16 & 0.08 & 1.84 \\
\hline \multicolumn{6}{|l|}{ Main effects } \\
\hline $\begin{array}{l}\text { Humble } \\
\text { Leadership }\end{array}$ & $\rightarrow$ & $\begin{array}{l}\text { Project } \\
\text { Management } \\
\text { Effectiveness }\end{array}$ & 0.15 & 0.05 & 2.70 \\
\hline $\begin{array}{l}\text { Employee } \\
\text { Creativity }\end{array}$ & $\rightarrow$ & $\begin{array}{l}\text { Project } \\
\text { Management } \\
\text { Effectiveness }\end{array}$ & 0.21 & 0.05 & 3.25 \\
\hline $\begin{array}{l}\text { Humble } \\
\text { Leadership }\end{array}$ & $\rightarrow$ & $\begin{array}{l}\text { Employee } \\
\text { Creativity }\end{array}$ & 0.18 & 0.05 & 3.26 \\
\hline HL_X_TMS & $\rightarrow$ & $\begin{array}{l}\text { Project } \\
\text { Management } \\
\text { Effectiveness }\end{array}$ & 0.17 & 0.04 & 2.89 \\
\hline HL_X_TMS & $\rightarrow$ & $\begin{array}{l}\text { Employee } \\
\text { Creativity }\end{array}$ & 0.11 & 0.04 & 2.59 \\
\hline
\end{tabular}

$\overline{\mathrm{SE}}$ = standard error; HL_X_TMS = interaction term of humble leadership and top management support.

We followed the previous method of bootstrap analysis as instructed by Preacher et al. (2007). Wang, Li [90] revealed that the average indirect effect evaluations generally do not shadow the ordinary suggestion and might result in bias. The bootstrap technique gives the most precise confidence intervals for estimating the indirect effect. Bootstrapping analysis is persuasive, as it distinguishes when the mediated effect sample distribution is skewed away from 0 [91]. Using 5000 data samples, we estimated $95 \%$ bias-corrected bootstrapped confidence intervals (CIs). The top and lower limit findings for employee creativity ignore 0 , implying that they were substantial by conventional standards. The bootstrap findings demonstrate that employee creativity has a favourable mediating effect between humble leadership and project management effectiveness $(\beta=0.04, \mathrm{SE}=0.02, p<0.05,95 \% \mathrm{CI}(0.013$, $0.088)$ ). The direct link between humble leadership and project management effectiveness 
was also important; thus, humble leadership and project management effectiveness were significantly mediated by employee creativity (see Table 4 ).

\section{Moderated Mediation}

To test Hypotheses 3a, 3b and 4, we have used Model 8 with the PROCESS macro analytical technique for testing moderated mediation effects [92,93]. We followed this method as previously suggested and performed by past literature $[77,78,93]$. We characterized the indirect impact with the practice of user-specified predictions, then assessed it using the bias-corrected bootstrap techniques to determine its magnitude [92]. Bootstrapping tests are useful, since they identify whenever the sampling distribution of the moderated mediating effects is skewed away from 0 [91]. Considering 5000 data samples, we estimated $95 \%$ bias-corrected bootstrapped confidence intervals (CIs). Conditional process analysis is known as a moderated mediation model, which is considered by the synchronised existence of a moderator (in this case, top management support) that strengthens the link between two other variables (in the present study, humble leadership and employee creativity and humble leadership and project management effectiveness) and a mediation (employee creativity). Table 2 demonstrates that the primary outcome of humble leadership and project management effectiveness was meaningfully moderated by top management support $(\beta=0.17, p<0.001)$. Top management support meaningfully moderates the link between humble leadership and employee creativity ( $\beta=0.11$, $p<0.001$ ), as showed in Table 4 . For explanatory reasons, employee creativity and project management effectiveness are displayed against humble leadership in Figures 1 and 2, separately, distinctly for high and low top management support (1 SD below and 1 SD above the mean, respectively). The bias-corrected percentile bootstrap outcomes further displayed that the implied indirect effect on humble leadership and project management effectiveness by employee creativity was inconsequential at $-1 \mathrm{SD}$ underneath the mean of TMS (Estimate $=0.04, \mathrm{SE}=0.01,95 \% \mathrm{CI}=(-0.15,0.15)$ ), but was substantial at $+1 \mathrm{SD}$ (Estimate $=0.012, \mathrm{SE}=0.008,95 \% \mathrm{CI}=(0.003,0.032)$, , which is in agreement with the notion that the top management support moderated both the direct and indirect paths. Hence, Hypotheses $3 \mathrm{a}, 3 \mathrm{~b}$ and $3 \mathrm{c}$ were supported.

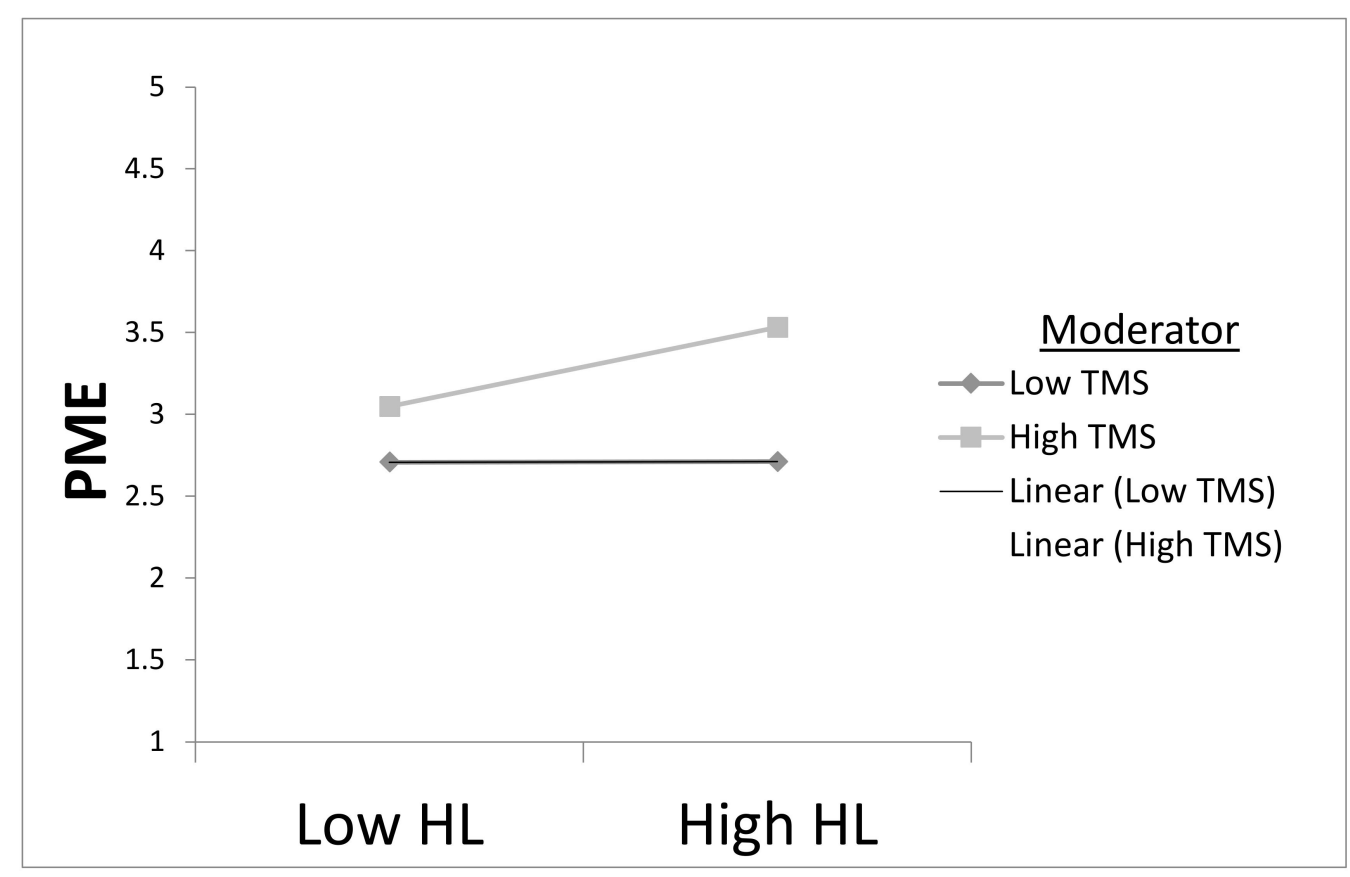

Figure 1. The conditional effect of top management support between humble leadership and effectiveness of project management. 


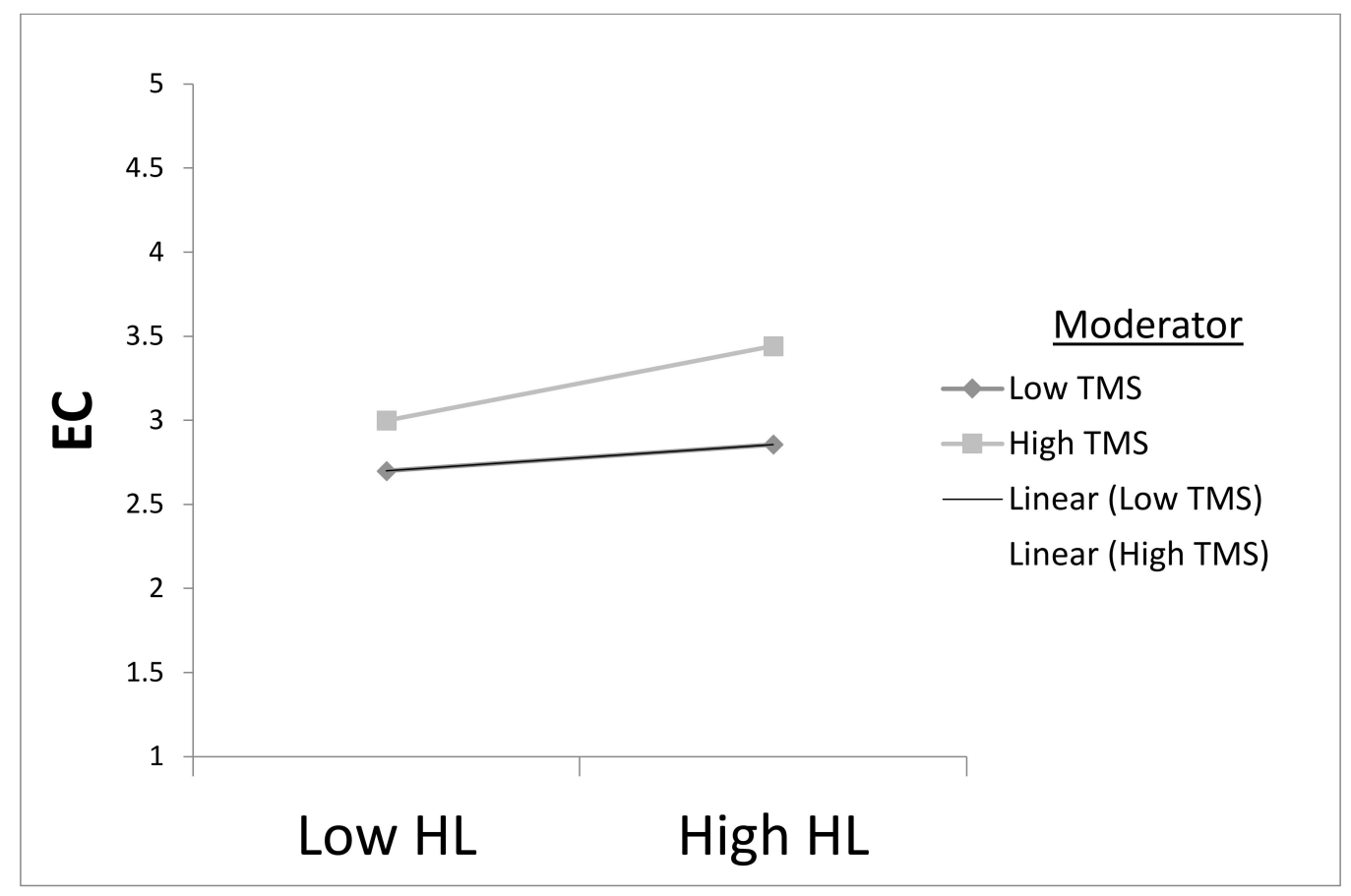

Figure 2. The interacting effect of top management support between humble leadership and employees' creativity.

\section{Discussion}

The present study investigated a framework empirically to determine the impact of humble leadership on project management effectiveness. A significant association was found between humble leadership and project management effectiveness. The humble project manager may persuade followers to believe in the cohesive notion of project management effectiveness, defined by stakeholders' efficiency and gratification. The study findings suggest that humility is an essential trait for a project manager to guarantee the effectiveness of project management. Furthermore, the current research covers the gap highlighted by earlier researchers, namely, that the literature on project management does not adequately define the leadership styles of the project manager in project management effectiveness [11].

The present study also points out that employee creativity partially mediates the connection between humble leadership and project management effectiveness, indicating that humble leadership contributes to the significant accomplishment of projects through employee creativity. This current finding indicates that innovative behaviour can contribute to a highly productive team [94]. This result reinforces past claims that organisations and project managers can stimulate creative solutions capabilities among employees through employees' innovative behaviours, ultimately enhancing project management effectiveness [95]. Overall, the current research findings submit that employee creativity is a beneficial factor in project management effectiveness, which might be accomplished through appointing team leaders with a high level of humility.

Top management support interacts with humble leadership and employee creativity. The study emphasises the importance that creativity boosts innovation in the organisation [96]. Zhang, Zheng [97] concluded that, even as workers grow their creative capacities, implementing innovative efforts in the organisational atmosphere that impact their behaviour is undertaken. Gumusluoğlu and Ilsev [98] discovered that top managers' transformational leadership could explicitly and indirectly encourage organisational creativity by developing a corporate culture that supports innovative behaviours. As a result, employees feel empowered to carry out innovative activities. Our findings depict that while executives support creativity inside the organisation, the humble leader may only slightly motivate 
team members toward innovation and swift resolutions for problems. Grant and Berry [99] considered that creating and signifying new ideas transformed an existing system and was supposed as pretty risky. The creation and execution of innovative ideas cannot be isolated from the individual who proposes the idea and typically follows leaders' appraisal.

Evidence was found that innovative behaviours improve when employees feel they need and welcome fresh innovations and easily share their ideas without being censored or penalised for faults [100]. Appraising and backing idea generation encourages staff to continually attempt new things to improve organisational processes and promote inventions continually. It contributes to reconstructing the framework, procedures and approaches of the organisation and upsurges project performance. According to Murat Ar and Baki [101], idea-generating includes promoting new ideas, marketing good ideas, developing solutions and inspiring workers to discover innovative conduct to solve problems. Mallén, Domínguez-Escrig [9] also indicated that the impact of a humble leadership on creativity is more substantial where specific organisational environments facilitate idea generation that is existing and involved, rather than inactive or absent. Risk-taking and idea implementation are closely associated with innovation [102]. As inventions need long-term risk-taking and commitment, staff must understand that senior executives encourage ambitious and creative ideas [64]. Some scholars stated that the development of risk-taking values in the organisation improves the leaders' workplace support and contributes to creativity [103].

Founded on Altunoğlu and Bulgurcu Gürel's (2015) results, too much management control in the organisation would inhibit risk-taking and development. It is necessary to assume that there is still a reasonable possibility of success when taking risks. It is therefore essential to be responsible for tracking and calculating risk-taking while, at the same time, have superior management accept mistakes [104]. It is essential to recognise that a risk-taking capacity ultimately inspires employee creativity. In this regard, with the support of top management, a humble project manager believes in the trial and error approach [49], which provides a balance in allowing freedom to employees to innovate quick solutions for problems [105].

\section{Practical Implications}

Such results may have a variety of relevant implications. Firstly, our findings show the value of a humble leader for project management effectiveness. Humility is a cherished and developable attribute. Leaders must be educated in humble working practices. It might be a method to raise the quality of matrix organisations, particularly in action learning [48]. Humility is a social and friendship trait that can formally and informally facilitate mutual teamwork among employees.

Our second research shows that creativity significantly mediates the link between humble leadership and project management effectiveness. The leader's job is to form a skilled team that can cope with their tasks, responsibilities, expertise and behaviour necessary for the practical outcomes and project objectives. One implication is the effectiveness of creativity techniques, including idea growth, idea understanding, idea application, strengthening of the organisational ties and clarity of responsibilities, activities and problems surrounding the project teams' functioning. Furthermore, this means a good chance of following projects, as the employee creativity element is appropriately applied. The previous work demonstrated that such an operational application produces a climate where subordinates feel confident, adding to the triumph of the venture [6].

Thirdly, our results show that top management's help in providing resources, institutional structures, communication, skills and strategies helps to increase project management effectiveness and creativity. The findings should enable the practitioners to handle projects more actively in which senior management takes their position seriously and ensures that managers furnish the necessary support. Upper management improves performance and conflict management methods through a supportive atmosphere [80]. The literature suggests that superior management supports project managers and followers to do their best and sustain high efficiency, ultimately leading to project management effectiveness [103]. 


\section{Limitations and Future Research Directions}

The cross-sectional breadth and the single data collection method limit our study. The notion that data obtained relates to IT industries and future research will explore civil projects. Our work considered the relations rather than the predictions between the primary constructs. In prospective studies, the experimental design can be used to find the reason and consequence of such associations. Subsequently, data were obtained using a single method; possible common method variance cannot be ignored. We attempted to tackle this issue to some degree by applying Harmans' one-factor test [106]. The findings revealed that the single factor accounted for only $23.4 \%$ of the difference, which was less than the threshold level of $50 \%$ [107], representing that common method bias is not a critical concern.

It will be fascinating to see how humble leadership resulted in negative consequences [16,108]. Zhong, Zhang [22] illustrate that a growing number of empirical research into humility has confirmed its beneficial impacts. However, it is unknown if humility leads to adverse effects, such as sluggish or less positive actions, that can conflict with the company's responses to quick alterations in the climate [109]. Future work should be carried out at a turning point where it negatively affects the impact of humility on project quality or other outcomes.

\section{Conclusions}

Improved awareness of the factors triggering project management effectiveness is vital for matrix organisations. We also saw that the humility of the project manager has both a direct and indirect impact on project management effectiveness within information technology projects. We also found the interacting role of superior management support among humble leadership, employee creativity and project management effectiveness. Therefore, matrix organisations must enhance humble traits in project managers through training and development techniques. As a result, it would create a collaborative project atmosphere that promotes employee creativity, such as idea creation, advancement and comprehension. We expect that our study will inspire further research into employee creativity and project management effectiveness.

Author Contributions: Conceptualization, M.A., L.Z. and Z.Z.; methodology, M.Z. and A.B.; writing, M.A., H.H., A.A.-M. and A.V.-M.; supervision, L.Z., H.H., A.A.-M. and A.V.-M.; project administration; H.H., A.A.-M. and A.V.-M.; funding acquisition, H.H., A.A.-M. and A.V.-M. All authors have read and agreed to the published version of the manuscript.

Funding: This research received no external funding.

Informed Consent Statement: Informed consent was obtained from the respondents of the survey.

Data Availability Statement: The data will be made available on request by the corresponding author.

Conflicts of Interest: The authors declare no conflict of interest.

\section{References}

1. Tabassi, A.A.; Roufechaei, K.M.; Ramli, M.; Bakar, A.H.; Ismail, R.; Pakir, A.H. Leadership competences of sustainable construction project managers. J. Clean. Prod. 2016, 124, 339-349. [CrossRef]

2. Floris, M.; Cuganesan, S. Project leaders in transition: Manifestations of cognitive and emotional capacity. Int. J. Proj. Manag. 2019, 37, 517-532. [CrossRef]

3. Kasapoğlu, E. Leadership styles in architectural design offices in Turkey. J. Constr. Eng. Manag. 2013, 140, 04013047. [CrossRef]

4. Koontz, H. Essentials of Management; Tata McGraw-Hill Education: New Delhi, India, 2010.

5. Yu, M.; Vaagaasar, A.L.; Müller, R.; Wang, L.; Zhu, F. Empowerment: The key to horizontal leadership in projects. Int. J. Proj. Manag. 2018, 36, 992-1006. [CrossRef]

6. Ali, M.; Zhang, L.; Shah Syed, J.; Khan, S.; Shah Adnan, M. Impact of humble leadership on project success: The mediating role of psychological empowerment and innovative work behavior. Leadersh. Organ. Dev. J. 2020, 41, 349-367. [CrossRef] 
7. Ali, M.; Li, Z.; Haider, M.; Khan, S.; Din, Q.M.U. Does humility of project manager affect project success? Confirmation of moderated mediation mechanism. Manag. Res. Rev. 2021. Available online: https://www.emerald.com/insight/content/doi/10 .1108/MRR-10-2020-0640/full/html (accessed on 16 July 2021). [CrossRef]

8. George, J.M.; Zhou, J. When openness to experience and conscientiousness are related to creative behavior: An interactional approach. J. Appl. Psychol. 2001, 86, 513. [CrossRef] [PubMed]

9. Mallén, F.; Domínguez-Escrig, E.; Lapiedra, R.; Chiva, R. Does leader humility matter? Effects on altruism and innovation. Manag. Decis. 2019, 58, 967-981. [CrossRef]

10. Zheng, J.; Wu, G.; Xie, H.; Li, H. Leadership, organizational culture, and innovative behavior in construction projects: The perspective of behavior-value congruence. Int. J. Manag. Proj. Bus. 2019, 12, 888-918. [CrossRef]

11. Ong, C.H.; Bahar, T. Factors influencing project management effectiveness in the Malaysian local councils. Int. J. Manag. Proj. Bus. 2019, 12, 1146-1164. [CrossRef]

12. Elbanna, A. Top management support in multiple-project environments: An in-practice view. Eur. J. Inf. Syst. 2013, 22, 278-294. [CrossRef]

13. Ali, M.; Li, Z.; Khan, S.; Shah Syed, J.; Ullah, R. Linking humble leadership and project success: The moderating role of top management support with mediation of team-building. Int. J. Manag. Proj. Bus. 2020, 14, 545-562. [CrossRef]

14. Yang, K.; Zhou, L.; Wang, Z.; Lin, C.; Luo, Z. Humble leadership and innovative behaviour among Chinese nurses: The mediating role of work engagement. J. Nurs. Manag. 2019, 27, 1801-1808. [CrossRef]

15. Mokhber, M.; Khairuzzaman, W.; Vakilbashi, A. Leadership and innovation: The moderator role of organization support for innovative behaviors. J. Manag. Organ. 2018, 24, 108-128. [CrossRef]

16. Ou, A.Y.; Tsui, A.S.; Kinicki, A.J.; Waldman, D.A.; Xiao, Z.; Song, L.J. Humble chief executive officers' connections to top management team integration and middle managers' responses. Adm. Sci. Q. 2014, 59, 34-72. [CrossRef]

17. Podgórska, M.; Pichlak, M. Analysis of project managers' leadership competencies: Project success relation: What are the competencies of polish project leaders? Int. J. Manag. Proj. Bus. 2019. [CrossRef]

18. Hobfoll, S.E. Conservation of resources: A new attempt at conceptualizing stress. Am. Psychol. 1989, 44, 513. [CrossRef]

19. Hobfoll, S.E. Conservation of resource caravans and engaged settings. J. Occup. Organ. Psychol. 2011, 84, 116-122. [CrossRef]

20. Ding, H.; Yu, E.; Chu, X.; Li, Y.; Amin, K. Humble Leadership Affects Organizational Citizenship Behavior: The Sequential Mediating Effect of Strengths Use and Job Crafting. Front. Psychol. 2020, 11, 11. [CrossRef]

21. Ou, A.Y.; Seo, J.; Choi, D.; Hom, P.W. When Can Humble Top Executives Retain Middle Managers? The Moderating Role of Top Management Team Faultlines. Acad. Manag. J. 2016, 60, 1915-1931. [CrossRef]

22. Zhong, J.; Zhang, L.; Li, P.; Zhang, D.Z. Can leader humility enhance employee wellbeing? The mediating role of employee humility. Leadersh. Organ. Dev. J. 2020, 41, 19-36. [CrossRef]

23. Qin, X.; Chen, C.; Yam, K.C.; Huang, M.; Ju, D. The double-edged sword of leader humility: Investigating when and why leader humility promotes versus inhibits subordinate deviance. J. Appl. Psychol. 2020, 105, 693-712. [CrossRef] [PubMed]

24. Walters, K.N.; Diab, D.L. Humble Leadership: Implications for Psychological Safety and Follower Engagement. J. Leadersh. Stud. 2016, 10, 7-18. [CrossRef]

25. Gonçalves, L. The relation between leader's humility and team creativity. Int. J. Organ. Anal. 2017, 25, 687-702. [CrossRef]

26. Kanwal, N.; Zafar, M.S.; Bashir, S. The combined effects of managerial control, resource commitment, and top management support on the successful delivery of information systems projects. Int. J. Proj. Manag. 2017, 35, 1459-1465. [CrossRef]

27. Ahmed, R.; Mohamad, N.A.B.; Ahmad, M.S. Effect of multidimensional top management support on project success: An empirical investigation. Qual. Quant. 2016, 50, 151-176. [CrossRef]

28. Boonstra, A. How do top managers support strategic information system projects and why do they sometimes withhold this support? Int. J. Proj. Manag. 2013, 31, 498-512. [CrossRef]

29. Maqbool, R.; Sudong, Y. Critical success factors for renewable energy projects; empirical evidence from Pakistan. J. Clean. Prod. 2018, 195, 991-1002. [CrossRef]

30. Fang, Y.-C.; Chen, J.-Y.; Wang, M.-J.; Chen, C.-Y. The Impact of Inclusive Leadership on Employees' Innovative Behaviors: The Mediation of Psychological Capital. Front. Psychol. 2019, 10, 1803. [CrossRef] [PubMed]

31. Cheung, S.Y.; Huang, E.G.; Chang, S.; Wei, L. Does being mindful make people more creative at work? The role of creative process engagement and perceived leader humility. Organ. Behav. Hum. Decis. Process. 2020, 159, 39-48. [CrossRef]

32. Zhang, X.; Bartol, K.M. Linking empowering leadership and employee creativity: The influence of psychological empowerment, intrinsic motivation, and creative process engagement. Acad. Manag. J. 2010, 53, 107-128. [CrossRef]

33. Mishra, P.; Bhatnagar, J.; Gupta, R.; Wadsworth, S.M. How work-Family enrichment influence innovative work behavior: Role of psychological capital and supervisory support. J. Manag. Organ. 2019, 25, 58-80. [CrossRef]

34. Akgün, A.E. Team wisdom in software development projects and its impact on project performance. Int. J. Inf. Manag. 2020, 50, 228-243. [CrossRef]

35. Patanakul, P. How to Achieve Effectiveness in Project Portfolio Management. IEEE Trans. Eng. Manag. 2020, 1-13. Available online: https: / /ieeexplore.ieee.org/document/8989787 (accessed on 16 July 2021). [CrossRef]

36. Unger, B.N.; Kock, A.; Gemünden, H.G.; Jonas, D. Enforcing strategic fit of project portfolios by project termination: An empirical study on senior management involvement. Int. J. Proj. Manag. 2012, 30, 675-685. [CrossRef] 
37. Ali, M.; Li, Z.; Durrani, D.K.; Shah, A.M.; Khuram, W. Goal clarity as a link between humble leadership and project success: The interactive effects of organizational culture. Balt. J. Manag. 2021, 16, 407-423. [CrossRef]

38. Rego, A.; Cunha, M.P.e.; Simpson, A.V. The perceived impact of leaders' humility on team effectiveness: An empirical study. J. Bus. Ethics 2018, 148, 205-218. [CrossRef]

39. Müller, R.; Turner, R. Leadership competency profiles of successful project managers. Int. J. Proj. Manag. 2010, 28, 437-448. [CrossRef]

40. Brière, S.; Proulx, D.; Flores, O.N.; Laporte, M. Competencies of project managers in international NGOs: Perceptions of practitioners. Int. J. Proj. Manag. 2015, 33, 116-125. [CrossRef]

41. Lin, X.; Chen, Z.X.; Herman, H.; Wei, W.; Ma, C. Why and when employees like to speak up more under humble leaders? The roles of personal sense of power and power distance. J. Bus. Ethics 2019, 158, 937-950. [CrossRef]

42. Cserháti, G.; Szabó, L. The relationship between success criteria and success factors in organisational event projects. Int. J. Proj. Manag. 2014, 32, 613-624. [CrossRef]

43. Chen, Y.; Liu, B.; Zhang, L.; Qian, S. Can leader "humility" spark employee "proactivity"? The mediating role of psychological empowerment. Leadersh. Organ. Dev. J. 2018, 39, 326-339. [CrossRef]

44. Ammons, D.N.; Roenigk, D.J. Exploring Devolved Decision Authority in Performance Management Regimes: The Relevance of Perceived and Actual Decision Authority as Elements of Performance Management Success. Public Perform. Manag. Rev. 2020, 43, 28-52. [CrossRef]

45. Argandona, A. Humility in management. J. Bus. Ethics 2015, 132, 63-71. [CrossRef]

46. Byrne, A.; Dionisi, A.M.; Barling, J.; Akers, A.; Robertson, J.; Lys, R.; Wylie, J.; Dupré, K. The depleted leader: The influence of leaders' diminished psychological resources on leadership behaviors. Leadersh. Q. 2014, 25, 344-357. [CrossRef]

47. Zhou, F.; Wu, Y.J. How humble leadership fosters employee innovation behavior: A two-way perspective on the leader-employee interaction. Leadersh. Organ. Dev. J. 2018, 39, 375-387. [CrossRef]

48. Wang, Y.; Liu, J.; Zhu, Y. Humble leadership, psychological safety, knowledge sharing and follower creativity: A cross-level investigation. Front. Psychol. 2018, 9, 1727. [CrossRef] [PubMed]

49. Owens, B.P.; Hekman, D.R. How does leader humility influence team performance? Exploring the mechanisms of contagion and collective promotion focus. Acad. Manag. J. 2016, 59, 1088-1111. [CrossRef]

50. Dirks, K.T.; Ferrin, D.L. The Role of Trust in Organizational Settings. Organ. Sci. 2001, 12, 450-467. [CrossRef]

51. Bos-Nehles, A.C.; Veenendaal, A.A.R. Perceptions of HR practices and innovative work behavior: The moderating effect of an innovative climate. Int. J. Hum. Resour. Manag. 2019, 30, 2661-2683. [CrossRef]

52. Hogan, S.J.; Coote, L.V. Organizational culture, innovation, and performance: A test of Schein's model. J. Bus. Res. 2014, 67, 1609-1621. [CrossRef]

53. Černe, M.; Hernaus, T.; Dysvik, A.; Škerlavaj, M. The role of multilevel synergistic interplay among team mastery climate, knowledge hiding, and job characteristics in stimulating innovative work behavior. Hum. Resour. Manag. J. 2017, 27, 281-299. [CrossRef]

54. Buller, P.F.; Bell, J.C.H. Effects of Team Building and Goal Setting on Productivity: A Field Experiment. Acad. Manag. J. 1986, 29, 305-328. [CrossRef]

55. Bradley John, H.; Hebert Frederic, J. The effect of personality type on team performance. J. Manag. Dev. 1997, 16, 337-353. [CrossRef]

56. Montani, F.; Vandenberghe, C.; Khedhaouria, A.; Courcy, F. Examining the inverted U-shaped relationship between workload and innovative work behavior: The role of work engagement and mindfulness. Hum. Relat. 2020, 73, 59-93. [CrossRef]

57. Dobni, C.B.; Klassen, M. The decade of innovation: From benchmarking to execution. J. Bus. Strat. 2021, 42, 23-31. [CrossRef]

58. Duan, Y.; Cao, G.; Edwards, J.S. Understanding the impact of business analytics on innovation. Eur. J. Oper. Res. 2020, 281, 673-686. [CrossRef]

59. Yuan, F.; Woodman, R.W. Innovative behavior in the workplace: The role of performance and image outcome expectations. Acad. Manag. J. 2010, 53, 323-342. [CrossRef]

60. Lee, J.-C.; Chen, C.-Y. Exploring the team dynamic learning process in software process tailoring performance: A theoretical perspective. J. Enterp. Inf. Manag. 2020, 33, 502-518. [CrossRef]

61. Kor, Y.Y. Experience-based top management team competence and sustained growth. Organ. Sci. 2003, 14, 707-719. [CrossRef]

62. Niehoff, B.P.; Enz, C.A.; Grover, R.A. The impact of top-management actions on employee attitudes and perceptions. Group Organ. Stud. 1990, 15, 337-352. [CrossRef]

63. Garavan, T.N. A Strategic Perspective on Human Resource Development. Adv. Dev. Hum. Resour. 2007, 9, 11-30. [CrossRef]

64. Schultz, C.; Graw, J.; Salomo, S.; Kock, A. How Project Management and Top Management Involvement Affect the Innovativeness of Professional Service Organizations-An Empirical Study on Hospitals. Proj. Manag. J. 2019, 50, 460-475. [CrossRef]

65. Hobfoll, S.E. Conservation of resources theory: Its implication for stress, health, and resilience. Oxf. Handb. Stress Health Coping 2011, 127-147. Available online: https:/ / www.oxfordhandbooks.com/view/10.1093/oxfordhb/9780195375343.001.0001 / oxfordhb-9780195375343-e-007 (accessed on 16 July 2021). [CrossRef]

66. Santos-Vijande, M.L.; López-Sánchez, J.Á.; Pascual-Fernandez, P. Co-creation with clients of hotel services: The moderating role of top management support. Curr. Issues Tour. 2018, 21, 301-327. [CrossRef]

67. Zwikael, O. Top management involvement in project management. Int. J. Manag. Proj. Bus. 2008, 1, 498-511. [CrossRef] 
68. Kuester, S.; Schuhmacher, M.C.; Gast, B.; Worgul, A. Sectoral Heterogeneity in New Service Development: An Exploratory Study of Service Types and Success Factors. J. Prod. Innov. Manag. 2013, 30, 533-544. [CrossRef]

69. Pieterse, A.N.; van Knippenberg, D.; Schippers, M.; Stam, D. Transformational and transactional leadership and innovative behavior: The moderating role of psychological empowerment. J. Organ. Behav. 2010, 31, 609-623. [CrossRef]

70. Berggren, C. The cumulative power of incremental innovation and the role of project sequence management. Int. J. Proj. Manag. 2019, 37, 461-472. [CrossRef]

71. Elenkov, D.S.; Manev, I.M. Top Management Leadership and Influence on Innovation: The Role of Sociocultural Context. J. Manag. 2005, 31, 381-402. [CrossRef]

72. Hobfoll, S.E.; Halbesleben, J.; Neveu, J.-P.; Westman, M. Conservation of Resources in the Organizational Context: The Reality of Resources and Their Consequences. Annu. Rev. Organ. Psychol. Organ. Behav. 2018, 5, 103-128. [CrossRef]

73. Stuckenbruck, L. Who determines project success. In Proceedings of the 18th Annual Seminar/Symposium, Montréal, CA, Canada, 20-25 September 1986; pp. 85-93.

74. Raziq, M.M.; Borini, F.M.; Malik, O.F.; Ahmad, M.; Shabaz, M. Leadership styles, goal clarity, and project success: Evidence from project-based organizations in Pakistan. Leadersh. Organ. Dev. J. 2018, 39, 309-323. [CrossRef]

75. Creasy, T.; Anantatmula, V.S. From Every Direction-How Personality Traits and Dimensions of Project Managers Can Conceptually Affect Project Success. Proj. Manag. J. 2013, 44, 36-51. [CrossRef]

76. Creasy, T.; Carnes, A. The effects of workplace bullying on team learning, innovation and project success as mediated through virtual and traditional team dynamics. Int. J. Proj. Manag. 2017, 35, 964-977. [CrossRef]

77. Hayes, A.F. Introduction to Mediation, Moderation, and Conditional Process Analysis: A Regression-Based Approach; Guilford Publications: Washington, DC, USA, 2017.

78. Shah Syed, J.; Shah Syed Asad, A.; Ullah, R.; Shah Adnan, M. Deviance due to fear of victimization: "emotional intelligence" a game-changer. Int. J. Confl. Manag. 2020, 31, 687-707. [CrossRef]

79. Owens, B.P.; Johnson, M.D.; Mitchell, T.R. Expressed humility in organizations: Implications for performance, teams, and leadership. Organ. Sci. 2013, 24, 1517-1538. [CrossRef]

80. Islam, Z.; Doshi, J.A.; Mahtab, H.; Ahmad, Z.A. Team learning, top management support and new product development success. Int. J. Manag. Proj. Bus. 2009, 2, 238-260. [CrossRef]

81. Kline, R.B. Principles and Practice Structural Equation Modeling; Guilford Publications: New York, NY, USA, 2015.

82. Jöreskog, K.G. Testing structural equation models. Sage Focus Ed. 1993, 154, 294.

83. Naseer, S.; Bouckenooghe, D.; Syed, F.; Khan, A.K.; Qazi, S. The malevolent side of organizational identification: Unraveling the impact of psychological entitlement and manipulative personality on unethical work behaviors. J. Bus. Psychol. 2020, 35, 333-346. [CrossRef]

84. Fornell, C.; Larcker, D.F. Evaluating Structural Equation Models with Unobservable Variables and Measurement Error. J. Mark. Res. 1981, 18, 39-50. [CrossRef]

85. Bagozzi, R.P. “Issues in the application of covariance structure analysis": A further comment. J. Consum. Res. 1983, 9, 449-450. [CrossRef]

86. Sarstedt, M.; Hair, J.F.; Ringle, C.M.; Thiele, K.O.; Gudergan, S.P. Estimation issues with PLS and CBSEM: Where the bias lies! J. Bus. Res. 2016, 69, 3998-4010. [CrossRef]

87. Anjum, M.A.; Liang, D.; Durrani, D.K.; Ahmed, A. Workplace ostracism and discretionary work effort: A conditional process analysis. J. Manag. Organ. 2019, 1-18. Available online: https://www.researchgate.net/publication/332094547_Workplace_ ostracism_and_discretionary_work_effort_A_conditional_process_analysis (accessed on 16 July 2021). [CrossRef]

88. Shah, S.J.; Zhang, L.; Khan, S.; Shah, S.A.A.; Durrani, D.K.; Ali, L.; Das, B. Terrorism vulnerability: Organizations' ambiguous expectations and employees' conflicting priorities. Int. J. Occup. Saf. Ergon. 2018, 26, 562-572. [CrossRef]

89. Zhang, Z.; Li, P.; Zhang, L.; Zheng, J.; Xue, Z. Helping neighbors and enhancing yourself: A spillover effect of helping neighbors on work-family conflict and thriving at work. Curr. Psychol. 2020,1-12. Available online: https://psycnet.apa.org/record/2020-4 5567-001 (accessed on 16 July 2021). [CrossRef]

90. Wang, Z.; Li, C.; Li, X. Resilience, leadership and work engagement: The mediating role of positive affect. Soc. Indic. Res. 2017, 132, 699-708. [CrossRef]

91. Shrout, P.E.; Bolger, N. Mediation in experimental and nonexperimental studies: New procedures and recommendations. Psychol. Methods 2002, 7, 422. [CrossRef] [PubMed]

92. Preacher, K.J.; Hayes, A.F. Asymptotic and resampling strategies for assessing and comparing indirect effects in multiple mediator models. Behav. Res. Methods 2008, 40, 879-891. [CrossRef]

93. Preacher, K.J.; Rucker, D.D.; Hayes, A.F. Addressing moderated mediation hypotheses: Theory, methods, and prescriptions. Multivar. Behav. Res. 2007, 42, 185-227. [CrossRef] [PubMed]

94. Vidmar, M. Enablers, Equippers, Shapers and Movers: A typology of innovation intermediaries' interventions and the development of an emergent innovation system. Acta Astronaut. 2021, 179, 280-289. [CrossRef]

95. Todt, G.; Weiss, M.; Hoegl, M. Mitigating Negative Side Effects of Innovation Project Terminations: The Role of Resilience and Social Support. J. Prod. Innov. Manag. 2018, 35, 518-542. [CrossRef]

96. Anderson, N.; Potočnik, K.; Zhou, J. Innovation and Creativity in Organizations: A State-of-the-Science Review, Prospective Commentary, and Guiding Framework. J. Manag. 2014, 40, 1297-1333. [CrossRef] 
97. Zhang, Z.; Zheng, J.; Cheng, B.; Zhong, J. Is a mindful worker more attentive? the role of moral self-efficacy and moral disengagement. Ethics Behav. 2020, 10, 1-16. [CrossRef]

98. Gumusluoğlu, L.; Ilsev, A. Transformational Leadership and Organizational Innovation: The Roles of Internal and External Support for Innovation. J. Prod. Innov. Manag. 2009, 26, 264-277. [CrossRef]

99. Grant, A.M.; Berry, J.W. The Necessity of Others is The Mother of Invention: Intrinsic and Prosocial Motivations, Perspective Taking, and Creativity. Acad. Manag. J. 2011, 54, 73-96. [CrossRef]

100. Yidong, T.; Xinxin, L. How Ethical Leadership Influence Employees' Innovative Work Behavior: A Perspective of Intrinsic Motivation. J. Bus. Ethics 2013, 116, 441-455. [CrossRef]

101. Murat Ar, I.; Baki, B. Antecedents and performance impacts of product versus process innovation: Empirical evidence from SMEs located in Turkish science and technology parks. Eur. J. Innov. Manag. 2011, 14, 172-206. [CrossRef]

102. Janssen, O. Job demands, perceptions of effort-reward fairness and innovative work behaviour. J. Occup. Organ. Psychol. 2000, 73, 287-302. [CrossRef]

103. Hermano, V.; Martín-Cruz, N. The role of top management involvement in firms performing projects: A dynamic capabilities approach. J. Bus. Res. 2016, 69, 3447-3458. [CrossRef]

104. Volberda, H.W.; Van Den Bosch, F.A.J.; Heij, C.V. Management Innovation: Management as Fertile Ground for Innovation. Eur. Manag. Rev. 2013, 10,1-15. [CrossRef]

105. Amabile, T.M.; Schatzel, E.A.; Moneta, G.B.; Kramer, S.J. Leader behaviors and the work environment for creativity: Perceived leader support. Leadersh. Q. 2004, 15, 5-32. [CrossRef]

106. Podsakoff, P.M.; MacKenzie, S.B.; Lee, J.-Y.; Podsakoff, N.P. Common method biases in behavioral research: A critical review of the literature and recommended remedies. J. Appl. Psychol. 2003, 88, 879. [CrossRef]

107. Chen, L.; Zhang, Z.-D.; Jia, W.-T. When and Why Leaders' Helping Behavior Promotes Employees' Thriving: Exploring the Role of Voice Behavior and Perceived Leader's Role Overload. Front. Psychol. 2020, 11, 2453. [CrossRef] [PubMed]

108. Weidman, A.C.; Cheng, J.T.; Tracy, J.L. The psychological structure of humility. J. Personal. Soc. Psychol. 2018, 114, 153. [CrossRef] [PubMed]

109. Eisenhardt, K.M. Making fast strategic decisions in high-velocity environments. Acad. Manag. J. 1989, 32, 543-576. 